DOI: $10.31393 /$ reports-vnmedical-2018-22(3)-28

UDC: $616.37-002$

\title{
ACTIVITY OF TNF- $\alpha$ IN PATIENTS WITH ACUTE AND CHRONIC PANCREATITIS
}

Ishcheikin K.le. ${ }^{1}$, Grebeniuk D.I. ${ }^{2}$, Liakhovchenko N.A. ${ }^{2}$, Zatserkovna O.M.2, Bilyk O.M. ${ }^{2}$

${ }^{1}$ Ukrainian Medical Stomatological Academy (Shevchenko str., 23, Poltava, Ukraine, 36011),

${ }^{2}$ National Pirogov Memorial Medical University, Vinnytsya (Pirogov str., 56, Vinnytsya, Ukraine, 21018)

Responsible for correspondence: e-mail: Doctor.Svo@gmail.com

Received 12 July 2018 p.; Accepted 20 August 2018 p.

Annotation. The aim of the study was to study the activity of TNF- $\alpha$ in patients with acute and chronic pancreatitis. The study included 86 patients with a confirmed diagnosis of acute edematous pancreatitis (group 1) and 36 patients with a confirmed diagnosis of chronic pancreatitis (group 2). A separate control group consisted of 70 conditionally healthy people, in whom laboratory and instrumental indices were determined similar to those in patients with acute and chronic pancreatitis. According to the aim and objectives of the study, we analyzed the levels of amylase, lipase and TNF- $\alpha$. The level of amylase in group 1 was $1664.1 \pm 185.2 \mathrm{U} / \mathrm{L}$ and was significantly $(p<0.01)$ different from the same indicator in group $2(81.2 \pm 40.2 \mathrm{U} / \mathrm{L})$ and in the control group $(75.2 \pm 23.2 \mathrm{U} / \mathrm{L})$. $A$ similar trend was observed in the study of lipase levels in all groups. Thus, the level of lipase in group 1 was $1058.5 \pm 120.7 \mathrm{U} / \mathrm{L}$ and was significantly $(p<0.01)$ different from the same indicator in group $2(37.6 \pm 22.1 \mathrm{U} / \mathrm{L})$ and in the control group $(42.7 \pm 13.8 \mathrm{U} / \mathrm{L})$. At the same time, there was no significant difference between the indicators of group 2 and the control group ( $p>0.05)$. Regarding the levels of TNF$\alpha$, its highest rates were observed in group $1-65.2 \pm 7.8 \mathrm{pg} / \mathrm{mL}$. In group 2, the level of this marker was $52.5 \pm 6.2 \mathrm{pg} / \mathrm{mL}$, and in the control group $-48.9 \pm 5.6 \mathrm{pg} / \mathrm{mL}$. In a statistical analysis, it turned out that the level of TNF- $\alpha$ was significantly higher $(p<0.05)$ in group 1 than in group 2 and the control group. Although we noted an increase in the numerical index of the level of TNF-a in group 2, however, there was no significant difference between this indicator in group 2 and the control group $(p>0.05)$. So, in acute pancreatitis, the levels of $T N F-\alpha$ were significantly higher $(p<0.05)$ than in chronic pancreatitis, but its concentration did not correlate with other studied parameters.

Keywords: acute pancreatitis, chronic pancreatitis, TNF- $\alpha$.

\section{Introduction}

One of the most actual problems of abdominal surgery for a long time remains the question of pancreatitis. Despite the continuous improvement of ideas about the nature and mechanisms of development of pancreatitis, the improvement of diagnostic and therapeutic measures, the problem of acute and chronic pancreatitis remains extremely relevant $[1,2]$.

The incidence of acute pancreatitis is increasing all over the world, and the disorder is now one of the most common reasons for hospitalization with a gastrointestinal condition $[3,4]$.

Although chronic pancreatitis is lower in incidence and prevalence than acute pancreatitis, it significantly affects patients' quality of life; it is characterized by chronic abdominal pain, frequent disease exacerbations, and exocrine and/or endocrine insufficiency $[5,6]$.

The annual incidence of acute pancreatitis ranges from 13 to $45 / 100,000$ persons, and chronic pancreatitis from 5 to $12 / 100,000$; the prevalence of chronic pancreatitis is about 50/100,000 persons [1]

In our opinion, the study of the activity of the inflammatory marker TNF- $\alpha$ in patients with acute and chronic pancreatitis is of scientific interest.

The aim of the study was to study the activity of TNF-? in patients with acute and chronic pancreatitis.

\section{Materials and methods}

The study was performed at the clinic of the Department of Endoscopic and Cardiovascular Surgery of National Pirogov Memorial Medical University, Vinnytsya. The study included 86 patients with a confirmed diagnosis of acute edematous pancreatitis (group 1) and 36 patients with a confirmed diagnosis of chronic pancreatitis (group 2). The verification of the diagnoses was performed according to the ICD-10 classification.

All patients were examined and received treatment in accordance with national and local protocols.

In addition to routine indicators, in accordance with the aim and objectives of the study, we studied the level of TNF- $\alpha$ in the serum by immunoferment analysis using a commercial ELISA kit (BioSource).

A separate control group consisted of 70 conditionally healthy people, in whom laboratory and instrumental indices were determined similar to those in patients with acute and chronic pancreatitis.

According to the aim and objectives of the study, we analyzed the levels of amylase, lipase and TNF- $\alpha$.

The obtained data were processed using the statistical software package SPSS 20.0 for Windows.

\section{Results. Discussion}

The average age of patients with acute pancreatitis was $46.2 \pm 16.2$ years, patients with chronic pancreatitis $45.8 \pm 17.9$ years, in the control group $-39.7 \pm 10.5$ years. The gender distribution in the groups was uniform, the number of men and women was almost the same.

Thus, the studied groups were homogeneous by gender-age distribution.

Levels of the main studied laboratory markers are shown in table 1. 
Table 1. Levels of the main laboratory markers under investigation.

\begin{tabular}{|c|c|c|c|}
\hline Parameter & $\begin{array}{c}\text { Group 1 } \\
\text { Acute } \\
\text { pancreatitis } \\
(\mathrm{n}=36)\end{array}$ & $\begin{array}{c}\text { Group 2 } \\
\text { Chronic } \\
\text { pancreatitis } \\
(\mathrm{n}=86)\end{array}$ & $\begin{array}{c}\text { Control } \\
\text { group } \\
(\mathrm{n}=70)\end{array}$ \\
\hline Amylase (U/L) & $1664.1 \pm 185.2$ & $81.2 \pm 40.2$ & $75.2 \pm 23.2$ \\
\hline Lipase $(\mathrm{U} / \mathrm{L})$ & $1058.5 \pm 120.7$ & $37.6 \pm 22.1$ & $42.7 \pm 13.8$ \\
\hline TNF- $\alpha(\mathrm{pg} / \mathrm{mL})$ & $65.2 \pm 7.8$ & $52.5 \pm 6.2$ & $48.9 \pm 5.6$ \\
\hline
\end{tabular}

As can be seen from table 1 , the level of amylase in group 1 was $1664.1 \pm 185.2 \mathrm{U} / \mathrm{L}$ and was significantly $(p<0.01)$ different from the same indicator in group 2 $(81.2 \pm 40.2 \mathrm{U} / \mathrm{L})$ and in the control group $(75.2 \pm 23.2 \mathrm{U} / \mathrm{L})$. At the same time, there was no significant difference between the indicators of group 2 and the control group ( $p>0.05$ ).

A similar trend was observed in the study of lipase levels in all groups. Thus, the level of lipase in group 1 was $1058.5 \pm 120.7 \mathrm{U} / \mathrm{L}$ and was significantly $(p<0.01)$ different from the same indicator in group $2(37.6 \pm 22.1 \mathrm{U} / \mathrm{L})$ and in the control group $(42.7 \pm 13.8 \mathrm{U} / \mathrm{L})$. At the same time, there was no significant difference between the indicators of group 2 and the control group ( $p>0.05)$.

Regarding the levels of TNF- $\alpha$, its highest rates were observed in group $1-65.2 \pm 7.8 \mathrm{pg} / \mathrm{mL}$. In group 2, the level of this marker was $52.5 \pm 6.2 \mathrm{pg} / \mathrm{mL}$, and in the control group - 48.9 $\pm 5.6 \mathrm{pg} / \mathrm{mL}$. In a statistical analysis, it turned out that the level of TNF- $\alpha$ was significantly higher $(p<0.05)$ in group 1 than in group 2 and the control group. Although we noted an increase in the numerical index of the level of TNF- $\alpha$ in group 2, however, there was no significant difference between this indicator in group 2 and the control group $(p>0.05)$.

TNF- $\alpha$ is a cytokine that causes unwanted effects in many different autoimmune and inflammatory diseases. It is a key regulator of other proinflammatory cytokines and of leukocyte adhesion molecules and it is a priming activator

\section{References}

1. Yadav, D. \& Lowenfels, A. B. (2013). The Epidemiology of Pancreatitis and Pancreatic Cancer. Gastroenterology, 144 (6), 1252-1261. doi: 10.1053/j.gastro.2013.01.068.

2. Machicado, J. D. \& Yadav, D. (2017). Epidemiology of Recurrent Acute and Chronic Pancreatitis: Similarities and Differences. Dig. Dis. Sci., 62 (7), 1683-1691. doi: 10.1007/s10620-017-4510-5.

3. Shah, A. P., Mourad, M. M. \& Bramhall, S. R. (2018) Acute pancreatitis: current perspectives on diagnosis and management. J. Inflamm. Res., 11, 77-85. doi: 10.2147/ JIR.S135751.

4. van Dijk, S. M., Hallensleben, N. D. L., van Santvoort, H. C., of immune cells. In recent years, several studies suggested that TNF- $\alpha$ plays a pivotal role in the pathogenesis of acute pancreatitis. Use of TNF- $\alpha$ in acute pancreatitis was assumed to predict disease severity and development of complications such as multiple organ failure and septic shock. It was concluded that during acute severe pancreatitis, pro- and anti-inflammatory cytokine response occured early and persisted in the systemic circulation for several days. They also observed an association with the disease severity at onset and outcome. But cytokine plasma concentrations were considered to be unable to predict death accurately in individual patients.

In our study we aimed to determine TNF- $\alpha$ levels in acute and chronic pancreatitis and evaluate the relation between TNF- $\alpha$ levels and pancreatic enzyme concentrations in two forms of the disease. Our results showed that TNF- $\alpha$ levels were significantly higher in acute pancreatitis than chronic pancreatitis. But no significant increase was observed in TNF- $\alpha$ production in chronic form of the disease compared to healthy individuals. Correlation analysis was performed between pancreatic enzymes such as amylase and lipase and TNF- $\alpha$ levels but we did not find any significant correlation.

\section{Conclusions and prospects forfurther development}

1. TNF- $\alpha$ levels are significantly higher in acute pancreatitis than chronic pancreatitis.

2. No significant increase was observed in TNF- $\alpha$ production in chronic form of the disease compared to healthy individuals.

3. There was no any significant correlation between pancreatic enzymes such as amylase and lipase and TNFa levels.

A comparative study of the levels of other cytokines in acute and chronic pancreatitis is promising.

Fockens P., van Goor, H., Bruno, M. J. \& Besselink, M. G. (2017). Acute pancreatitis: recent advances through randomised trials. Gut, 66 (11), 2024-2032. doi: 10.1136/gutjnl2016-313595.

5. Kirkegard, J., Mortensen, F. V. \& Cronin-Fenton, D. (2017) Chronic Pancreatitis and Pancreatic Cancer Risk: A Systematic Review and Meta-analysis. Am. J. Gastroenterol., 112 (9), 1366-1372. doi: 10.1038/ajg.2017.218.

6. Gupte, A., Goede, D., Tuite, R. \& Forsmark, Ch. E. (2018). Chronic pancreatitis. BMJ, 361, k2126. doi: https://doi.org/10.1136/ bmj.k2126.

\section{АКТИВНІСТЬ ТNF- $\alpha$ У ХВОРИХ НА ГОСТРИЙ ТА ХРОНІЧНИЙ ПАНКРЕАТИТ}

\section{Іщейкін К.Є., Гребенюк Д.І., Ляховченко Н.А., Зацерковна О.М., Білик О.М.}

Анотація. Мета дослідження - вивчити активність TNF- $\alpha$ у хворих на гострий та хронічний панкреатит. У дослідження було включено 86 хворих із підтвердженим діагнозом гострого набрякового панкреатиту (група 1) та 36 хворих із підтвердженим діагнозом хронічного панкреатиту (група 2). Окрему контрольну групу склали 70 умовно здорових людей у яких визначалися лабораторні та інструментальні показники аналогічні до таких у пацієнтів із гострим та хронічним панкреатитом. Відповідно до мети та завдань дослідження нами було проаналізовано рівні амілази, ліпази та TNF- $\alpha$. Рівень амілази

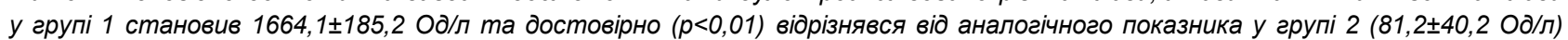
та у контрольній групі (75,2士23,2 Од/л). Аналогічна тенденція прослідковувалася і при дослідження рівнів ліпази у всіх 


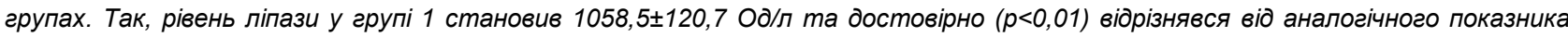

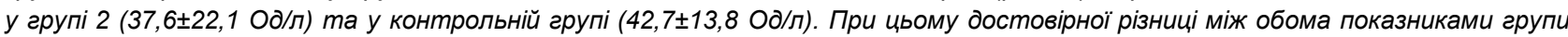
2 та контрольної групи виявлено не було (p>0,05). Щодо рівнів TNF- $\alpha$, то найвищі його показники спостерігалися у групі 1 -

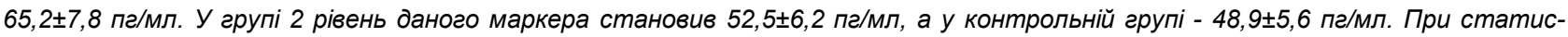
тичному аналізі виявилося, що рівень TNF- $\alpha$ був достовірно вищий $(p<0,05)$ у групі 1 , ніж у групі 2 та контрольній групі. Хоча ми відмічали збільшення числового показника рівня TNF- $\alpha$ у групі 2, проте достовірної різниці між даним показником у групі 2 та контрольній групі виявлено не було (p>0,05). Отже при гострому панкреатиті рівні TNF- $\alpha$ були достовірно вищими $(p<0,05)$, ніж при хронічному панкреатиті, але його концентрація не корелювала із іншими досліджуваними показниками. Ключові слова: гострий панкреатит, хронічний панкреатит, TNF- $\alpha$.

\section{АКТИВНОСТЬ ТNF- $\alpha$ ТА У БОЛЬНЫХ ОСТРЫМ И ХРОНИЧЕСКИМ ПАНКРЕАТИТОМ}

Ищейкин К.Е., Гребенюк Д.И., Ляховченко Н.А., Зацерковная Е.Н., Билык А.Н.

Аннотация. Цель исследования - изучить активность TNF- $\alpha$ у больных острым и хроническим панкреатитом. В исследование было включено 86 больных с подтверждённым диагнозом острого отёчного панкреатита (группа 1) и 36 больных $c$ подтверждённым диагнозом хронического панкреатита (группа 2). Отдельную контрольную группу составили 70 условно здоровых людей, у которых определялись лабораторные и инструментальные показатели аналогичны таковым у пациентов с острым и хроническим панкреатитом. Согласно цели и задач исследования нами были проанализированы уровни

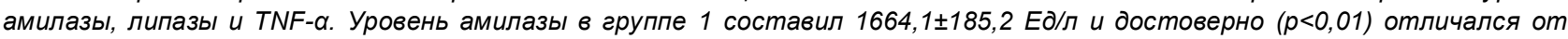

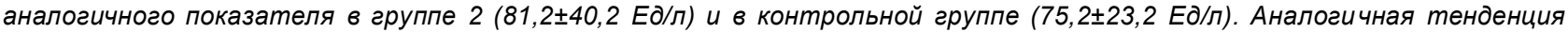

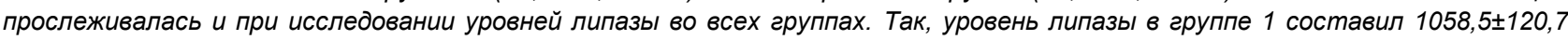
Ед/л и достоверно $(p<0,01)$ отличался от аналогичного показателя в группе $2(37,6 \pm 22,1$ Ед/л) и в контрольной группе $(42,7 \pm 13,8$ Ed/ת). При этом достоверной разницы между обоими показателями группы 2 и контрольной группы выявлено не

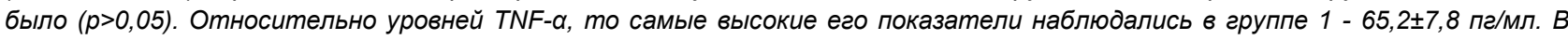

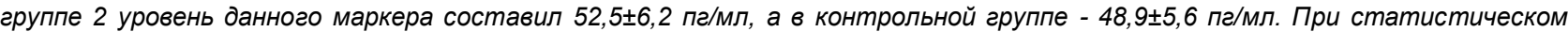
анализе оказалось, что уровень TNF- $\alpha$ был достоверно выше $(p<0,05)$ в группе 1 , чем в группе 2 и контрольной группе. Хотя мы отмечали увеличение числового показателя уровня TNF- $\alpha$ в группе 2, однако достоверной разницы между данным показателем в группе 2 и контрольной группе выявлено не было ( $p>0,05)$. Таким образом, при остром панкреатите уровни TNF- $\alpha$ были достоверно выше $(p<0,05)$, чем при хроническом панкреатите, но его концентрация не коррелировала с другими исследуемыми показателями.

Ключевые слова: острый панкреатит, хронический панкреатит, TNF- $\alpha$. 